\title{
A BIBLIOMETRIC ANALYSIS ON HERITAGE BUILDING INFORMATION MODELING (HBIM) TOOLS
}

\author{
Nur Tayyibe COŞGUN ${ }^{a 1}$, Hasan Fevzi ÇÜGEN ${ }^{b 2}$, Semra ARSLAN SELÇUK ${ }^{c 3}$ \\ Sorumlu Yazar: Nur Tayyibe COŞGUN; E-mail:nurerbk@gmail.com
}

\begin{abstract}
The protection of cultural heritage begins with a difficult documentation process that requires the collection and processing of many data and the collaboration of experts from different disciplines. Today, Building Information Modeling (BIM) which allows a three-

\section{Keywords}

Heritage Building Information Modelling

HBIM

Documentation

Bibliometric Analysis dimensional (3D) virtual representation of buildings and their surroundings together with materials, textures, etc., and can work integrated with data collection methods such as terrestrial laser scanners (TLS), has also started to be used in cultural heritage structures. Called as Heritage Building Information Modeling (HBIM), this system includes the documentation process in which a $3 \mathrm{D}$ representation of the architectural heritage is created by parametrically modeling together with its historical data, in order to contribute to the preservation of cultural heritage. In this study, in order to examine the change and development of the "modeling tools" used from past to present by revealing the conceptual framework, requirements and stages of the HBIM system a bibliometric research has been conducted. Accessed from the Web of Science database through the relevant keywords of 146 articles published between 2008 and 2021 have been evaluated. The results of the study have been shared by scientific mapping analysis of articles focusing on modeling.
\end{abstract}

\section{TARIHI YAPILARDA BİLGI MODELLEME (HBIM) ARAÇLARI ÜZERİNE BİBLIYYOMETRIK BİR ANALİZ \\ Özet}

\section{Anahtar \\ Kelimeler}

Tarihi Yap1 Bilgi

Modelleme

HBIM

Belgeleme

Bibliyometrik Analiz
Kültürel mirasın korunması, birçok verinin toplanması, işlenmesi ve farklı disiplinlerden gelen uzmanların bir arada çalışmasını gerektiren zorlu bir belgeleme süreci ile başlamaktadır. Günümüzde, modern yapıları çevreleriyle beraber üç boyutlu (3B) sanal temsilini oluşturabilen, aynı zamanda görsel olmayan malzeme, doku vb. verileri içerebilen, yersel lazer tarayıcılar (YLT) gibi veri toplama yöntemleriyle entegre çalışabilen Yapı Bilgi Modelleme (BIM) yazılımları kültürel miras yapılarında da kullanılmaya başlamıştır. Tarihi Yapı Bilgi Modellemesi (HBIM) olarak isimlendirilen bu sistem, kültürel mirasın korunmasına katk1 sağlamak amacıyla yapının tarihsel verilerini de içeren ve parametrik modelleme araçları ile 3B temsilinin oluşturulduğu belgeleme sürecini ifade eder. Bu çalışmada, HBIM sisteminin kavramsal çerçevesi, gereklilikleri ve aşamaları ortaya konarak kullanılan modelleme araçlarının dünden bugüne değişim ve gelişimini incelemek amacıyla Web of Science veri tabanından 2008-2021 yılları arasında ilgili anahtar kelimelerle ulaşılmış ve modelleme konusuna odaklanan 146 makalenin bilimsel haritalaması/analizi yapılmış ve sonuçları paylaşılmıştır.

\footnotetext{
${ }^{a}$ Gazi Üniversitesi Mimarlık Fakültesi Mimarlık Yüksek Lisans Öğrencisi, ${ }^{1}$ ORCID ID: 0000-0002-2164-3289

${ }^{b}$ Gazi Üniversitesi Mimarlık Fakültesi Mimarlık Yüksek Lisans Ögrencisi, ${ }^{2}$ ORCID ID: 0000-0001-6566-3727

${ }^{c}$ Gazi Üniversitesi Mimarlık Fakültesi Ögretim Üyesi, ${ }^{3}$ ORCID ID: 0000-0002-2128-2858
} 


\section{INTRODUCTION}

Heritage buildings, which shed light on the past and build bridges with the future, are damaged or even destroyed by earthquakes, floods, humaninduced hazards (wars, pollutions, neglects), and other natural disasters. Architectural heritage should be "protected" to be passed on to future generations (Osello, 2018). The protection of architectural heritage requires the collection, arrangement, sharing of a large number of data and transforming all this knowledge into information to obtain a precise restoration project. This process, which includes both the documentation of the current situation, the processing of periodic information from archival sources and the determination of material properties specific to the building, also requires the gathering of experts from different disciplines. Evaluation and documentation of historic buildings requires a continuous collaboration of essential processes such as geometric analysis, structural observation, deterioration research, social and economic analysis (Oreni, Brumana, Georgopoulos and Cuca, 2013). The realization of this process with a collective effort and in a single working environment, if possible, has the potential to play a key role in the documentation and preservation of historic buildings (Allegra, 2020).

BIM, which provides spatial and functional representation of buildings with parametric objects, is widely used in planning, design and project management stages. Thanks to its many features such as visualization, data management, cost calculation, it serves activities such as energy management, emergency management, retrofit planning. In recent years, it has started to be used for the documentation of existing structures as a result of researches such as maintenance, renovation, and the life cycle of the building (Volk, 2014).

In the documentation of heritage buildings, difficulties in matching the data obtained with traditional methods results with the difficulty of understanding the real conditions of the building. In this context, BIM is accepted as an important tool in the preservation of heritage buildings with its potential in the process of documentation and restoration projects (Murphy et al., 2017; Bruno et al., 2019; Allegra, 2020).
HBIM (Heritage Building Information Modeling), which has entered the literature in the last decade and is used to express the use of BIM in heritage buildings, is a customized BIM adaptation for the preservation of architectural heritage. It was defined for the first time as a "prototype library of parametric objects based on historical architectural data" (Murphy, McGovern, Pavia, 2009) by an academic Murphy, who conducted research at the Dublin University Institute of Technology. Although the concept of HBIM was named by Murphy, the theoretical foundations of this concept were laid by Arayıc1 (2008), who "explained how to prepare digital documents for reconstruction and restoration by using point cloud data collected with 3D laser scanners on an existing structure in BIM". The pioneer of all these studies is seen as the Getty Conservation Institute's RecordDIM's (Recording, Documentation, \& Information Management) researches done between 20032007. (Arayici, Counsell, Mahdjoubi, Nagy, Hawwās, Dweidar, 2017)

In recent years, the number of studies on HBIM has increased and diversified. Many of the studies claim that these technologies allow heritage buildings to be managed at different stages, from the planning stage to management and from virtual reconstruction to the restoration process (Pocobelli, 2018; Al-Muqdadi, 2020).

In addition, the data collected about the building on a model or the effort to create a model with the collected data can provide a platform to test the consistency of the obtained data (Arayici et al. 2017). In recent years, researchers trying to automate the HBIM process have focused on creating a parametric library that can represent a variety of real objects, and where predefined digital objects are accessible and modifiable (Pocobelli, 2018).

Basically, HBIM can be defined as "the use of software that allows keeping a digital record of historic buildings using a combination of remote sensing (laser scanning, digital photogrammetry), digital surveying and manual techniques" (Murphy et al. 2017). Heritage buildings recorded in this way are called "smart objects" since their dimensions, materials and details can be updated when any changes are 
required (Pocobelli, 2018). Smart objects save time and money in the long run as they allow all kinds of collaboration, modification and updating, and provide comprehensive data that will help research for future studies (Worrell, 2015). At the same time, it is also possible to get the taxonomic classification of each element that provides the models according to their characteristics such as typology, structural function, location (Nieto, 2016).

Within the scope of this research, a comprehensive review of the existing literature has been made in order to understand the "development of modeling tools and the change in research trends" since the emergence of the HBIM concept, and evaluations have been made for future studies by analyzing the obtained bibliometric maps and quantitative data.

\section{HISTORIC BUILDING INFORMATION MODELLING (HBIM)}

Digital data play an important role in documenting the architectural heritage, successfully transferring it to the future and protecting it with the right data (Güleç, 2007). In order to see the structural damages and the structural interventions of the architectural heritage to be protected, many kinds of data such as dimensions and geometric data of the building, architectural style and architectural grammar, material information, facade deterioration and interventions, and different levels of detail should be collected before starting the work (Pocobelli, 2018).

Lack of information and/or inconsistency in the preservation and maintenance activities of heritage buildings can lead to errors and sometimes irreparable damages. An architectural heritage does not only contain physical and historical features, but also contains a large amount of information about many social, political, economic and cultural issues related to its environment. In order to process these huge amount of data, experts from different fields need to come together. Documenting heritage buildings can also be difficult to interpret and understand, as they often contain large amounts of data (Simeone, 2014). For this reason, it is possible to argue that the success of documentation will play a key role in the preservation of heritage buildings. Processing and managing all this data in a single file has been possible by integrating BIM into the documentation process (Conti, Fiorini, Massaro, Santoni, \& Tucci, 2020).

Traditional methods such as step, span and folding meters used to measure and record the data of existing structures have been replaced by new generation technologies in recent years. For example, "laser technologies used to determine distances, digital photography technologies used to detect geometry and texture, software technologies used to model structures and their surroundings" (Murphy, 2012) are some of them.

$\mathrm{BIM}$ is the digitization and computational representation of the physical and functional properties of any object. In other words, thanks to BIM, the 3D representation of the building can contain functional, semantic and topological information as well as geometric data (Radanovic, 2020). Other advantages of BIM technologies in the conservation of architectural heritage can be mentioned as, allowing data sharing in a multidisciplinary team, providing multiple design options, providing coordinatebased modeling, allowing the integration of data such as historical information / photographs / drawings into the model, coordinating with systems such as GIS (Geographical Information Systems), CAFM (Computer-Aided Facility Management) (Antonopoulou, 2017). At the same time, these technologies offer the opportunity to work on a single model for necessary analyzes on issues such as structural analysis for existing buildings, facility management, fire safety design, and visualizations such as augmented reality and virtual reality. In fact, it is thought that these technologies can contribute to the development of the society's awareness on architectural heritage with open source software in the future. (Kamaruzaman, 2019).

On the other hand, it is a well-known fact that these technologies are not widely used today. The root of this problem is that most BIM software only contains data/library for new buildings, so they do not have predefined parametric objects for heritage buildings. In other words, the modeling of heritage buildings must be created from scratch (Dore and Murphy, 2017). As a result, although BIM software is not 
flexible enough to model the irregular and complex structure of heritage buildings, the HBIM system developed can simultaneously study the data of the building from different sources on a single model (Pellicer, 2016).

\subsection{Stages of HBIM}

HBIM is a three-dimensional parametric representation that allows data of heritage buildings to be managed. Provides a georeferenced $3 \mathrm{D}$ model by combining nongeometric information about structures with geometric data obtained using point clouds, orthophotos and photogrammetric techniques (Oreni, Georgopoulos, Cuca, 2014)

Laser Scanning/ Photogrammetric Measurement

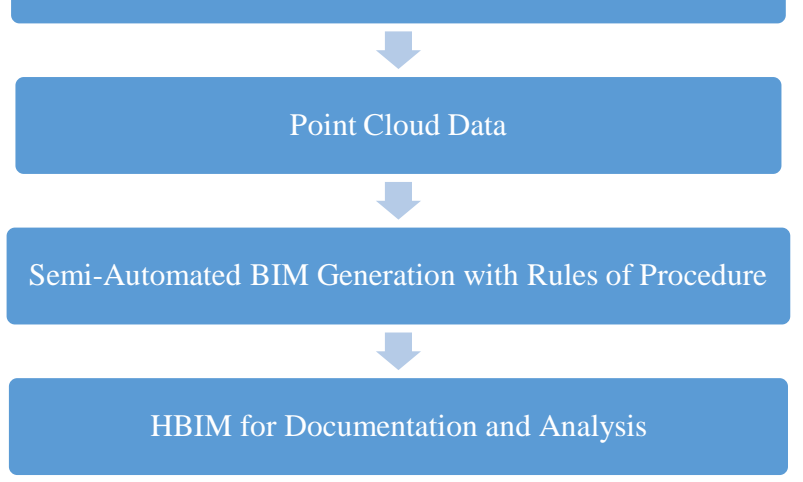

Figure 1. Suggested stages of HBIM (Dore, 2015)

As seen in Figure 1, a laser scan or photogrammetric measurement is performed to acquire the data in the first step of HBIM. In the second stage, the data is processed as point cloud data so that it can be transferred to the BIM software (Figure 2). In the third stage, the historical structure is modeled with point cloud data in accordance with the procedural rules. (Figure 3). The created geometry can be filtered by adjusting the parameters so that it can work correctly with the data that may come later. After the created model is fully matched with the survey data, documents can be created automatically thanks to plans, facade drawings, sections and 3D perspectives (Dore, Murphy, McCarthy, Brechin, Casidy, Dirix, 2015).
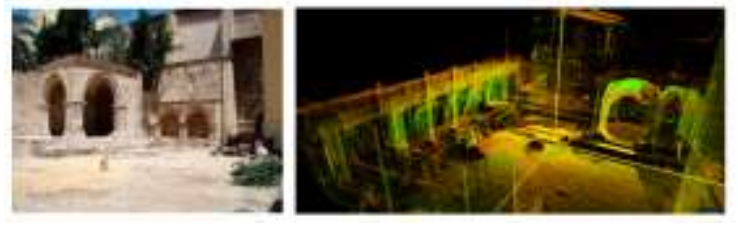

Figure 2. Data generated by laser scanning in Patio Sur (Palomar, 2018)
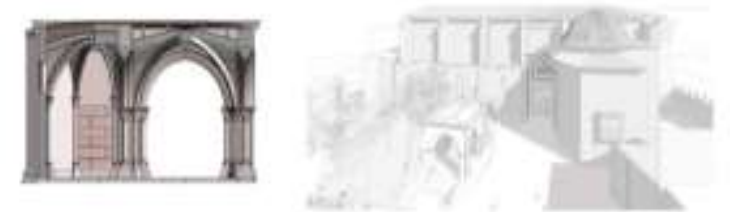

Figure 3. BIM model created with point cloud data in Patio Sur (Palomar, 2018)

In conclusion, the three main phases of HBIM can be summarized as data collection, modeling with BIM software and transfer of historical data. These steps serve to complete the process of modeling, defining, classifying and associating objects. (Chiabrando, Sammartano, \& Spanò, 2016)

\subsubsection{Data Collection and Processing}

Many measurement techniques are used to obtain the data required for building BIM in buildings. Some of these techniques are laser scanning technology, orthophotos and photogrammetric techniques. Among these techniques, laser scanning technology is the most preferred method due to its speed of capturing data and the level of detail and accuracy in the resulting point cloud information. (Murphy, Dore, 2014) Unlike conventional measurements, laser scanning data can convert material and structural information covering the entire building into digital records (Korumaz, 2016).

Laser scanners are divided into two specialized areas, aerial photogrammetry and terrestrial scanners. Each has a resolution range and sensitivity suitable for target use. In particular, terrestrial laser scanning (TLS) works by means of a laser beam that travels back and forth towards the scanned area and measures angles/distances with millimeter to centimeter accuracy. (Çelik, 2020; Facundo, 2018). With TLS, triangulation, the scanned object creates a "point cloud" that must be post-processed and then converted into a 3D model. While collecting data with TLS, the scanner must be placed in different positions relative to the object, since there may be elements that block the view. Data 
extracted from different scans creates partial point clouds and then combined (Figure 4) (López, 2018).

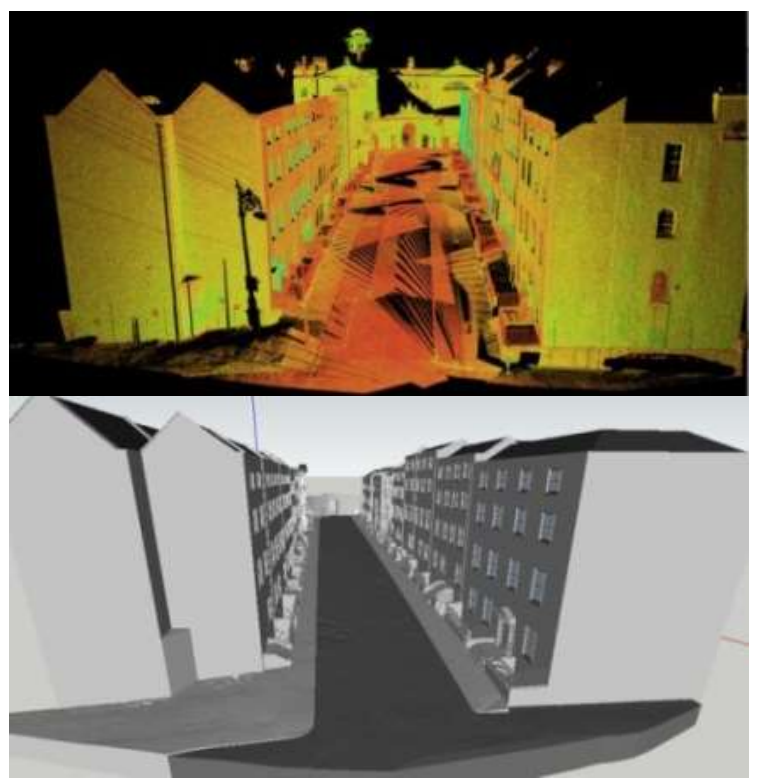

Figure 4. Model of Henrietta Street obtained with laser scanner data (Chenaux, 2019)

Photogrammetric techniques are also quite suitable for capturing data. These techniques use images taken from different viewpoints to record the 3D geometry of a building or object. Photogrammetric techniques can produce results similar to laser scanning, such as point clouds, mesh models, and orthophotos (Murphy and Dore, 2014).

To generate the point cloud, it is possible to use high-resolution images with the Structure from Motion (SfM) methodology, which is based on the principle that "four non-coplanar surfaces can be detected by three ortho-graphic projections". This method consists of photographs moving the camera constantly, trying to detect convergent images, and then digitally reconstructing the geometry. (Pocobelli, 2018)

Orthophotos are photo-realistic models that include the width, depth, and height of an object. Orthophoto represents data for a particular plane on the $\mathrm{x}, \mathrm{y}$, and $\mathrm{z}$ axis; so this can represent height, plan or section of an object. (Figure 5) Generating an orthophoto from point cloud data allows all image and geometric data to be exported for visualization or further processing in CAD (Computer Aided Design), VRML
(Virtual Reality Modeling Language) and other modeling platforms (Murphy, 2012).

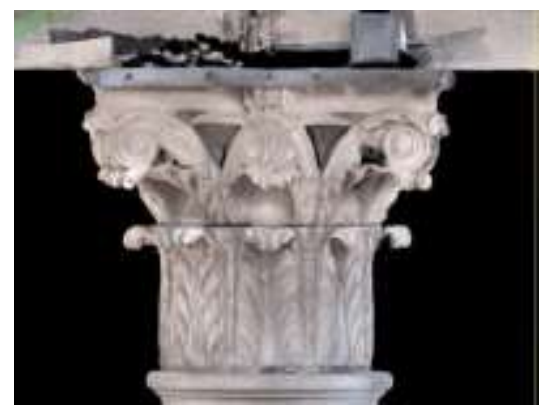

Figure 5. Orthophoto example (Murphy, 2017)

\subsubsection{D Modelling}

BIM is used in the architecture, engineering and construction industries for planning, designing, constructing and facility management. (Figure 6) With BIM technology, first a model of a building is created digitally, in other words, it helps them visualize what needs to be built in a simulated environment (Azhar, 2011).

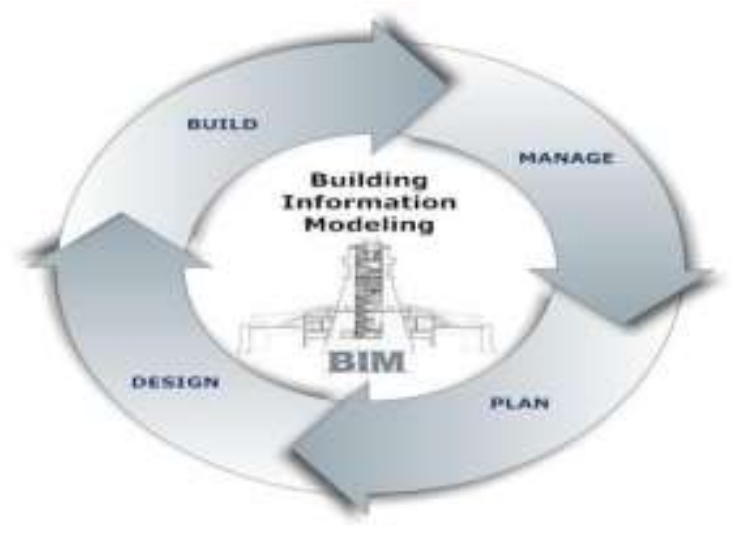

Figure 6. BIM Model (Logothetis, Delinasiou, Stylianidis, 2015)

The third step, "3D parametric modeling", starts with point clouds and semantic data to be integrated into the BIM platform. For this step, the integrated point cloud is manually segmented and delimited to be able to define the objects to be modeled. The existing BIM library and externally created objects are then used to parametrically model the studied object or structure. (Figure 7) This type of 3D modeling can also be described as a "reverse engineering" process. The segmentation of point clouds represents key steps to identify, identify accurate surfaces, and facilitate tracking or modeling of parametric objects. These steps can be performed semi-automatically or fully automatically through new object recognition and point cloud 
segmentation algorithms as well as improvements added to BIM platforms. The semi-automatic process is directed by the user in the form of adjustments, sections, inferences of faces made on the point cloud. The fully automated process is still under development because the qualitative data of a place or object is difficult to read by the software and due to the limitations of the algorithms and software complements used (López, 2018 ).

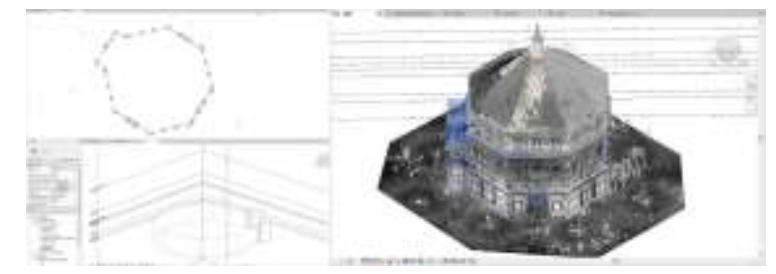

Figure 7. BIM example created from point cloud data (Biagini, 2020)

\subsubsection{Software for HBIM}

There are several 3D modeling software that can design solid parametric models for BIM platforms, 3D to view models, and analyzers to analyze 3D models between BIM platforms. 3D modeling platforms for HBIM can be listed as ArchiCad, Tekla Structures, Bentley System, Autodesk Revit. For 3D viewers Tekla BIMsight, Navisworks Freedom and Sketchup are used commonly. Finally, analyzers include Ecotect Analysis, DAYSIM, Energy Plus. Apart from these platforms, many BIM supported platforms with prominent functionality, adaptability and connection systems can be used in HBIM systems (Facundo, 2018).

Among these programs, ArchiCad helps to obtain complex three-dimensional models by following the same steps as traditional drawing methods. It also has the possibility to save projects in various formats compatible with most common 3D modeling software (Koncsag \& Man, 2015). Thanks to ArchiCad, properties such as spatial, physical and structural can be set as parameters of objects, visualization can be customized according to research or project needs. (Anton, Medjdoub, Shrahily, \& Moyano, 2018). By enabling the use of parametric and adaptive objects, ArchiCAD has the potential to ease the workload of future object reworkers (Boeykens, 2012).
Autodesk Revit software, preferred for its accessibility, graphical versatility and general use with an education license, is a BIM platform suitable for accurately modeling both regular and irregular surfaces and geometric difficulties of different elements. (Angulo-Fornos \& Castellano-Roman, 2020; Lopez, Lerones, Llamas, Gomez-Garcia-Bermejo, \& Zalama, 2018). However, although Revit offers customizable libraries for material, it does not have the library that would be needed for modeling a historic building, so adding images or textures is required. (Quattrini, Malinverni, Clini, Nespeca, \& Orlietti, 2015). Revit Family Editor does not support adding point cloud files in traditional formats. For this reason, it is necessary to export them in dxf format in order to separate the source points for the objects to be modeled and add them to the Revit Family Editor (Rubio, 2019).

Dynamo Revit plugin, which is a graphical version of the algorithmic software connected to the BIM software, allows advanced processing of the information in the model, both graphically and alphanumeric, through Python languagebased graphical programming routines. (Jiang et al., 2020). Dynamo is an open source visual programming environment that offers the ability to design and use BIM elements by programming interactively with designers (Yang, Lu, Murtiyoso, Koehl, \& Grussenmeyer, 2019). It can also be used to create a "family" in Revit by automatically assigning parameters stored in Excel to the corresponding objects (Yang, Cheng, \& Wang, 2020).

FreeCAD software, a CAD/BIM parametric modeler, offers the possibility to modify the default libraries and schemas related to certain aspects of its objects. Because this software can be more flexible than other BIM software, different types of information can be stored and managed in a single HBIM platform (Diara \& Rinaudo, 2020). The number and qualities of software that can be used for HBIM are increasing day by day with the developing technology.

\subsubsection{Problems Encountered in the Modeling Stage}

Although significant progress has been made in the use of BIM in the documentation and 
management of cultural heritage, BIM software also has some disadvantages. Documentation of architectural heritage requires many formal procedures. In addition, since there is no parametric object library in the BIM software for the inheritance object, it must be done manually by the operator due to its complex and irregular features.

Parametric design of building elements through point cloud is a time-consuming and error-prone process and today there is no automation or software that can directly transform point cloud to BIM (Facundo, 2018). Since most BIM libraries have been focused on modern buildings, another problem can be mentioned as the lack of appropriate parametric object library for heritage buildings. As a result, modeling existing and historic buildings often requires many components to be built from scratch, which can be a very time-consuming process (Dore and Murphy, 2017). In addition, information loss may occur as huge amount of data is collected and processed in this process (Rua \& Gil, 2014; Bagnolo, Argiolas, \& Cuccu, 2018).

Problems encountered in most studies are related to the modeling phase due to software constraints. Considering the variety of forms in heritage buildings and the limitations of the software available in the market, the difficulty of the modeling process will be understood (Scianna, 2020). Because BIM software does not allow very complex and highly detailed solutions to be realized (Adami, Scala, \& Spezzoni, 2017). Several programs can be used in the modeling process to overcome these constraints. Although the variety of file formats is seen as an advantage that allows experts from different fields to work together, problems can be seen due to integration between file formats and the need to use more programs (Abbate, Invernizzi, \& Spano, 2020).

While the simplification of geometry revealed by a large number of data and point clouds in heritage buildings indicates an insufficient level of detail for documentation and conservation analysis, the presence of complex geometric elements also creates difficulties in the modeling phase. Here, creating precise graphical representations by BIM tools is very important. (Woodward \& Heesom, 2019).

\subsubsection{Level of Development}

In BIM modeling, it may not always be necessary to represent an architectural element with a high level of detail. The Level of Detail (LoD) of a BIM object is the graphical accuracy to be achieved in modelling. This level depends on both the scale range of the representation (maximum and minimum) and the purpose of the final model (Scianna, 2020) The use of BIM requires a definition of "level of development" to limit misunderstandings in the model. Although the definition of LoD varies in different standards, it is generally accepted as a rating system that describes the complexity of a model (Sun, Xie, Zhang, \& Cao, 2019).

This concept is regulated according to the definitions and protocols of the American Institute of Architects (AIA) (Bruno, De Fino, \& Fatiguso, 2018). Defined by the AIA, The LoD of BIM protocol (Scianna, 2020) is as follows, LoD 100: Conceptual representation, LoD 200: General modeling (preliminary project),LoD 300/350: Design (final project), LoD 400: Structural design (application project), LoD 500: Asbuilt project.

The LoD level of a BIM object consists of a geometric and semantic component. According to the standard UNI 11337:2017 valid in Italy, it recognizes the Geometry Level (LOG) and the Knowledge Level (LOI) as the two components of the LoD. The LOG consists of a graphical representation of the model, the LOI represents the semantic description associated with it. Also, the level of detail to be achieved should be outlined with the ultimate purpose of the model in mind. In Italy, levels LoD up to A-G according to UNI 11337 define different levels of detail, including Level of Geometry (LOG) and Level of Information (LOI). The contents of the levels are indicated in Table 1.

Moreover, the purpose of LoD classifications is to understand the accuracy level of objects with geometric parameters by taking into account the complexity of shapes in modeling architectural objects of existing buildings. In addition, the continuous digital flow in BIM requires the adoption of a shared language for interoperability between software products that need to classify tasks and information in a single team or stakeholders. (Bruno et al., 2018). 
Table 1. Object properties from LOD A to LOD G

\begin{tabular}{|c|c|c|c|}
\hline & Definition & LOG & LOI \\
\hline LOD A & Symbolic Object & Symbolic 2d Representation & Rough Positioning \\
\hline LOD B & Generic Object & Approximated Volumes & Definition of Function \\
\hline LOD C & Defined Object & Detailed Representation & Definition of Metrics and Materials \\
\hline LOD D & Detailed Object & Detailed Representation & $\begin{array}{c}\text { Detailed Materials, } \\
\text { Stratiggraphies, Structures }\end{array}$ \\
\hline LOD E & Specific Object & $\begin{array}{c}\text { Complete Representation of the } \\
\text { Object }\end{array}$ & $\begin{array}{l}\text { Technical İnformation about } \\
\text { the Construction }\end{array}$ \\
\hline LOD F & Executed Object & As Lod E & Maintenance Manual, Certifications \\
\hline LOD G & Updated Object & As Lod E or As Modified & Maintenance Date \\
\hline
\end{tabular}

Resource: (Scianna, 2020)

\section{METHODOLOGY}

\subsection{Research Method}

This section includes the research methods and tools used to reach the bibliometric analysis conducted within the scope of the research. The flow chart of the research method is shown in Figure 10.

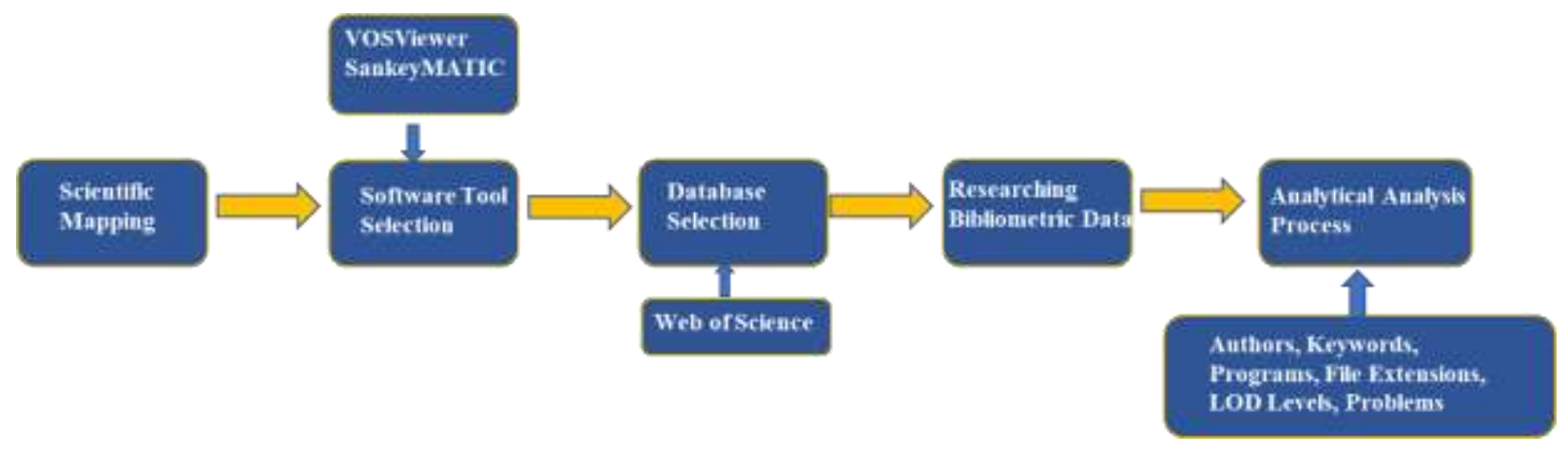

Figure 10. Methodology of research

In order to examine the development of the modeling tools used in HBIM and the change in research trends in the field, first of all, the tools for the bibliometric analysis were decided, and then the database was selected to achieve related articles. In this context, firstly, the research area was limited to the research and review articles published between 2008-2021 with the "HBIM" keyword, title and abstract combinations from the Web of Science (WoS) database. A total of 146 articles focusing on modeling tools were included in the research by examining the 316 articles achieved. The articles were classified under the headings of "programs/software, interoperability, LOD levels and problems" in the HBIM process of the researchers. Relationships between these categories were analyzed by SankeyMATIC software, and the title information such as author information and keywords were analyzed through VOSviewer. As a result of the analyzes, the change and development of the modeling tools used in HBIM from the past to the present were evaluated and future remarks were explained. 


\subsection{Scientific Analysis and Mapping}

Scientific mapping or bibliometric analysis aims to release the structural and dynamic aspects of research in the field. Through this method huge amount of information such as the relationship between disciplines, fields and authors can be explained by scientific maps (Cobo, LópezHerrera, Herrera-Viedma, \& Herrera, 2011). Scientific mapping has become a convenient tool used by researchers to describe large bibliometric data for a variety of purposes. (Wuni, Shen, \& Osei-Kyei, 2019). In this research, bibliometric analysis and mapping of HBIM-related published studies were performed to obtain an objective view of the current and future trends in the field.

\subsubsection{Database and Software Tool Selection}

An online library has been created on the EndNote platform for the articles to be analyzed within the scope of the research. Many databases such as PubMed, LISTA, Scopus, Web of Science can be accessed through EndNote. Web of Science (WoS), one of the largest publisherindependent citation indexes with access to multiple databases, was chosen to provide data.

Research was conducted on journal articles with the keyword HBIM through WoS. The VOSviewer program was used to create and visualize bibliometric networks that are compatible with both the EndNote Library and the WOS database. Networks created in VOSviewer can include journals, researchers, or individual publications and can be created based on citation, bibliographic matching, co-citation, or co-authorship relationships. And finally, SankeyMATIC was used to create a Sankey diagrams, which makes it easy to see the data flow.

\subsubsection{Creation and Analysis Process of Bibliometric Data}

Within the scope of the research, "HBIM" has been chosen as a specialized keyword in order to make an accurate determination about the Information Modeling of Heritage and to access more resources. Journal articles were searched by selecting the "Title/Keyword/Abstract" category in the WOS database with the keyword "HBIM" without any time limit. As a result of this search 316 articles were reached from 2008 to February 2021. These articles were examined separately by focusing on "modeling tools" and 146 articles were selected for analysis. Selected articles were examined in detail and classified for analysis. The softwares were evaluated in two categories: First is BIM software selected as a modeling tool, and the second is supplemental software being used for other purposes. Here the purpose was to see the prevalence, adequacy and diversity of the software used to obtain HBIM.

By specifying the file extensions of the programs used in the "Interoperability" heading, the ability of working together of these programs was examined. In the "Problems" section, the problems encountered while using BIM programs were highlighted. Precision levels of the models were examined under the title of "LOD". The relationship between these categories was visualized with a Sankey diagram and interpreted. Thus, by performing data analysis, an investigation of the tools and environments used for modeling heritage buildings has been made from the past to the present.

\subsection{Findings}

In this section, the bibliometric data obtained from the articles on modeling tools in the field of HBIM were processed under the headings of "Authors, Keywords, Programs, Interoperability, Model levels, Problems" via VOSviewer and SankeyMATIC, and mapping and analysis were revealed. The authors of the articles selected within the scope of the research are associated using the "reference-citation network" option in VOSviewer (Figure 11). The size of the nodes is directly related to the citation rates of the authors. The bars connected to the nodes show author relationships. R. Brumana and F. Banfi from Politecnico di Milano University came first among 155 authors. Considering the author relations, it was seen that the authors living in the same geographical region work together more and establish a more linear connection with the authors in other regions.

When the keywords of the selected articles were analyzed, the keywords "Cultural Heritage" and "Point Clouds" come to the fore when we ignore the main keywords our search such as HBIM and BIM. When the relationship between the keywords was examined, different combinations were observed. (Fig. 12) 


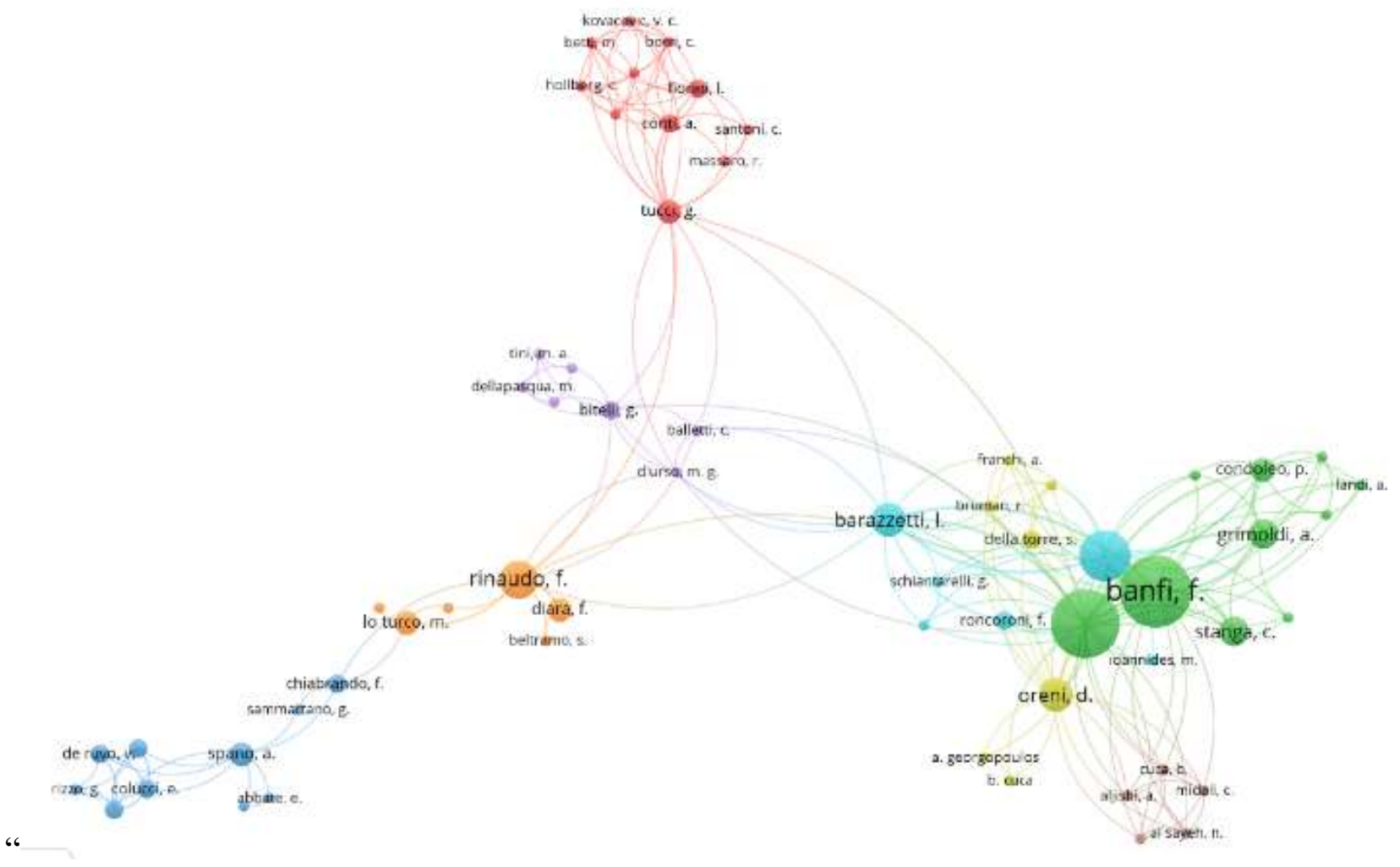

Figure 11. Author-Cite relations

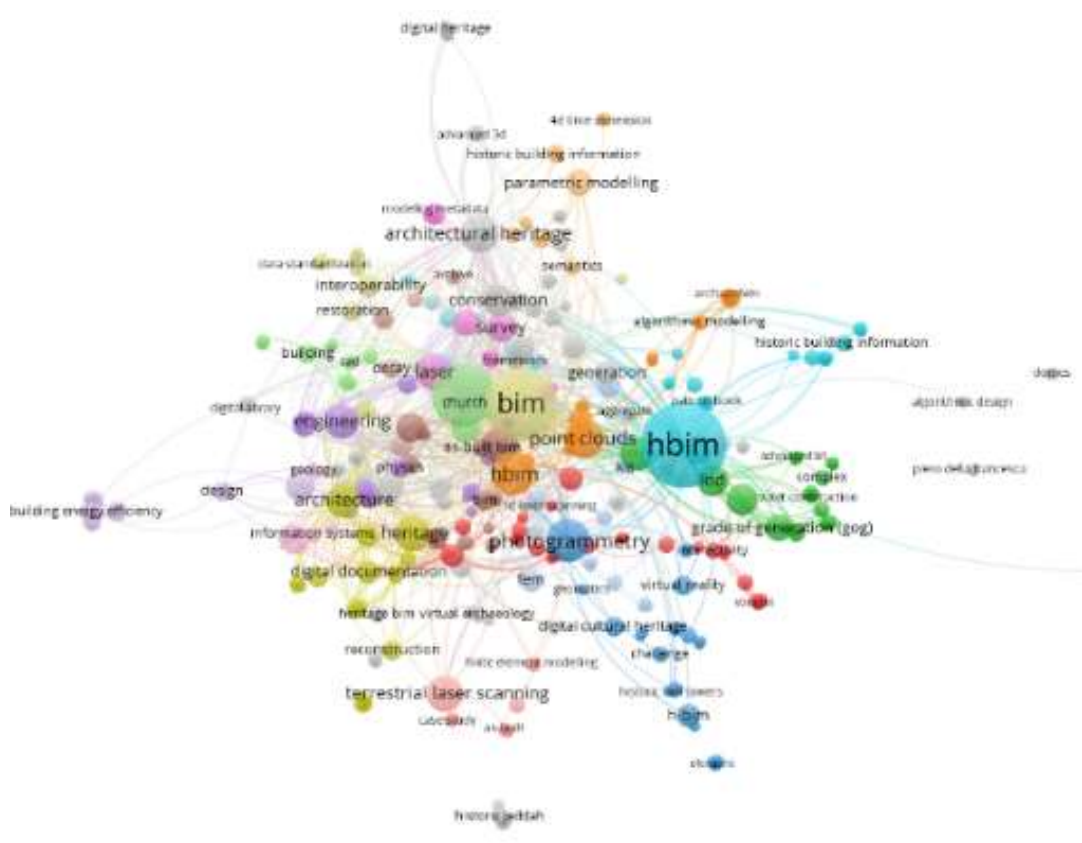

Figure 12. Keywords analysis 


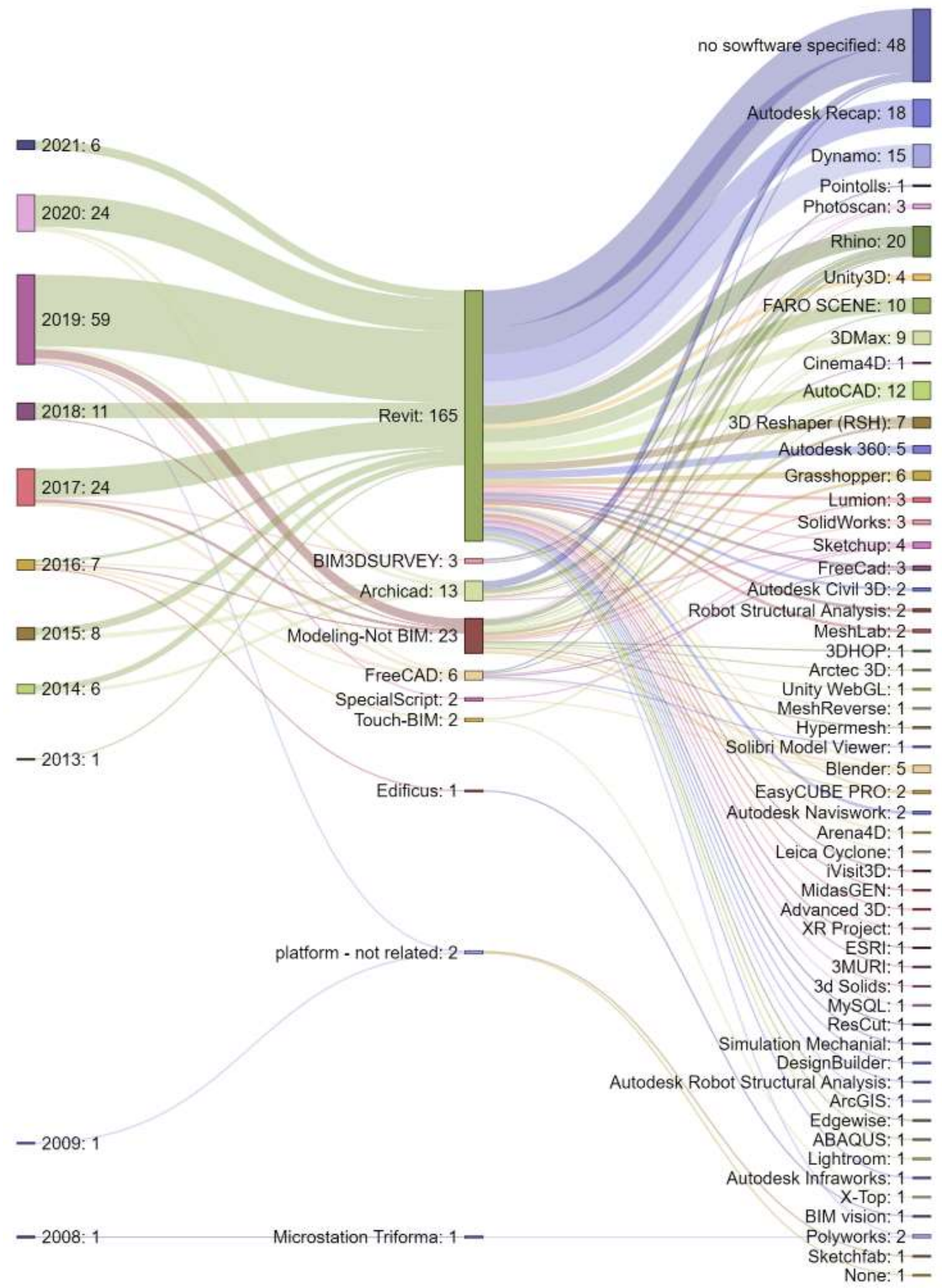

Figure 13. Distribution of supplementary software and BIM software used in the analysed studies by years 
It is clear from the Figure 13 that there has been an increase in the number of studies on HBIM over the years. In most of the studies examined, it is seen that non-BIM-based 3D software have been used together with BIM software, especially to overcome the problem of modeling complex structures. In this study, BIM and nonBIM based software were evaluated separately and the relationships of the software were investigated. Studies that focused only on modeling and did not use BIM software were evaluated under the category of "Modelling-not BIM".

Although it was understood that different software was used in addition to BIM software in the studies, the qualification "no software specified" was made for the software whose name was not mentioned. (see Figure 13)

The process of using BIM software in the modeling of heritage buildings took place when Murphy introduced the concept of HBIM and started using ArchiCAD. When we look at the BIM software used in the research, the software like Revit, FreeCAD and ArchiCAD stand out. When the rates are analyzed by years, it has been seen that the ArchiCAD program is still used, but the dominance is in the Revit program. One of the main reasons for this can be said that Revit provides an education license, making it easier for the user to access.

In addition, experts working with traditional protection methods are the programs developed by Autodesk, which is the Autocad and Revit software company that is mostly used in documenting with 2D drawing. For this reason, they can be easily used together. (see Figure 13)

Again, Figure 13 shows that Revit is able to connect with many programs, that is, it stands out in terms of interoperability. In the studies with Revit, it is remarkable that Rhino and Grasshopper connections are more common instead of Autocad and Dynamo included in the autodesk software package. Accordingly, although Revit software is interoperable between file formats without any problems, it can be concluded that it is not sufficient for modeling without supplementary software. It can be said that these softwares used for point cloud generation, acquisition of surfaces and data transformation are an important part of this process. Modeling heritage buildings is a process that requires the use of different programs for data collection and processing, as well as BIM software. For this reason, file formats have of great importance when transferring data between programs. When the articles analyzed in this research are examined from this point of view, in the modeling stage, the preferences of experts mostly appeared as IFC, OBJ, DWG, DXF and FBX formats. (see Figure 14)

Industry Foundation Class (IFC) is a neutral data exchange standard developed by "building SMART" to facilitate interoperability between BIM platforms in the AEC industry. (AnguloFornos \& Castellano-Roman, 2020). The IFC open file format is frequently preferred due to its compatibility with BIM software. (Anton et al., 2018; Facundo, 2018).

What can be considered surprising in graphics is that, the more frequent use of an object-oriented format such as FBX, instead of formats such as DXF and DWG that are mostly non-objective and are often used for 2D drawings. DXF and DWG appear as a format that comes from the 2D document production processes that have been used as a classical method for many years. Within the light of this knowledge, it is possible to conclude that although the point cloud is directly used in model production processes, 2D drawings are still used.

Another remarkable aspect can be said as the variety of file formats. The variety of file extensions has naturally more than software numbers. This can be interpreted as, some formats are not software dependent, but are developed only for data transfer. Although this diversity facilitates data sharing it also results in data loss.

A range of software is needed to produce HBIM. In addition to the BIM software used in this respect, the proliferation and development of supplementary software also positively affects HBIM. However, existing BIM software is proper for buildings newly designed and for this reason they tend to serve standards by using libraries. From this perspective, problems are encountered as a result of using these softwares in the modeling of existing buildings. The 
tendency of diversify the software used to overcome these problems can be clearly seen from the graph.

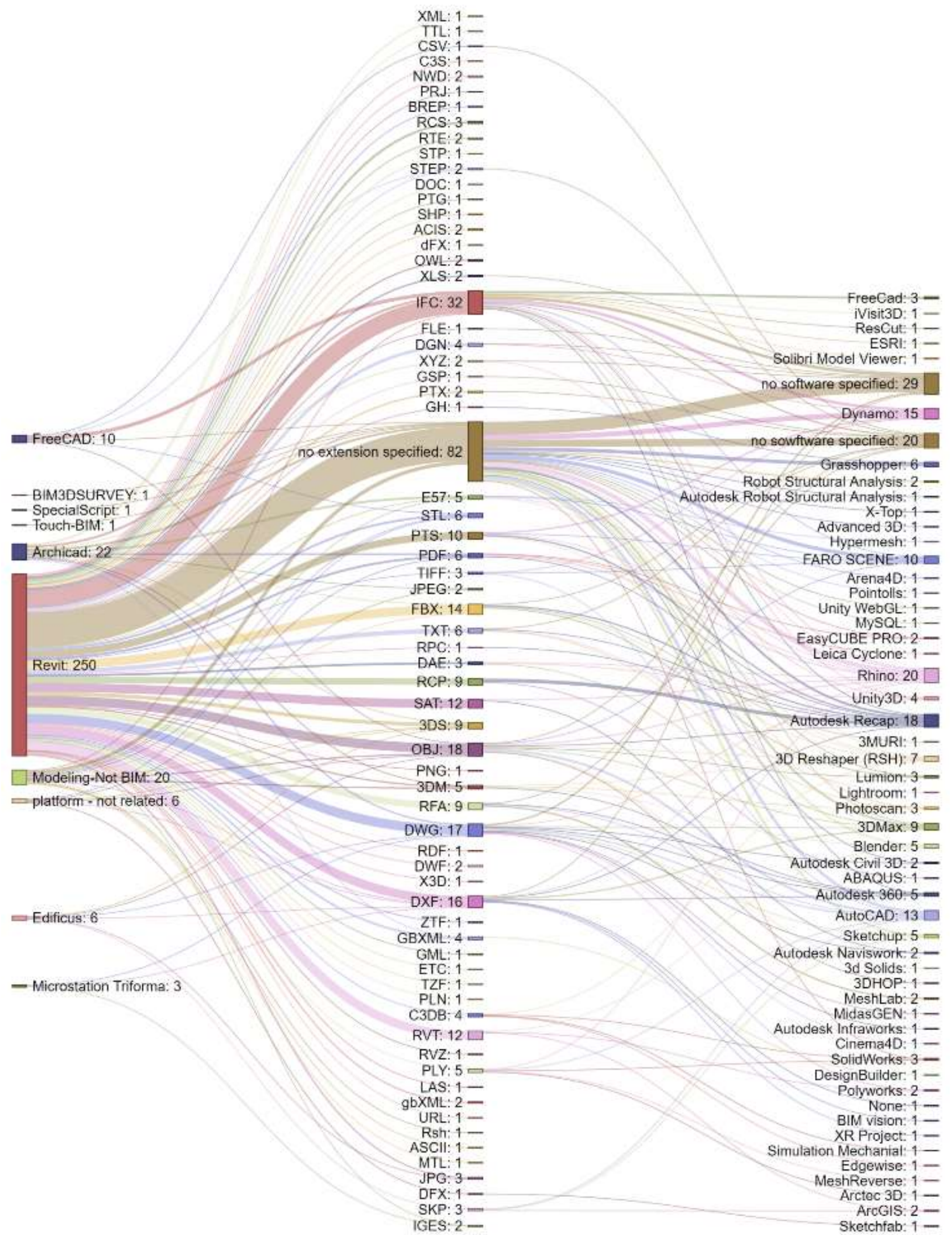

Figure 14. Relationship between program and file extensions used in HBIM 
The reviewed articles mainly focus on 5 problems. The first problem is "software limitations", which are caused by the inadequacy of the software in the modeling phase. Another is the necessity of multiple software requirement in the data collection, processing, and modeling phase instead of taking place in a single environment. This problem leads to information loss, which can be called as another problem. Finally, the modeling process is labor intensive. This problem is described as "not automated" in the Figure 15.
Model production can be done for a specific purpose. This difference in needs determining the detail level of the model. The concept of LOD is a concept used to indicate the model level. Although the aim in modeling heritage buildings is to reach the highest level of detail that can be achieved, a standard description is needed for model production. Since all other problems have a relationship with the LOD level, "software, problems and LoD levels" are examined together in Figure 15.

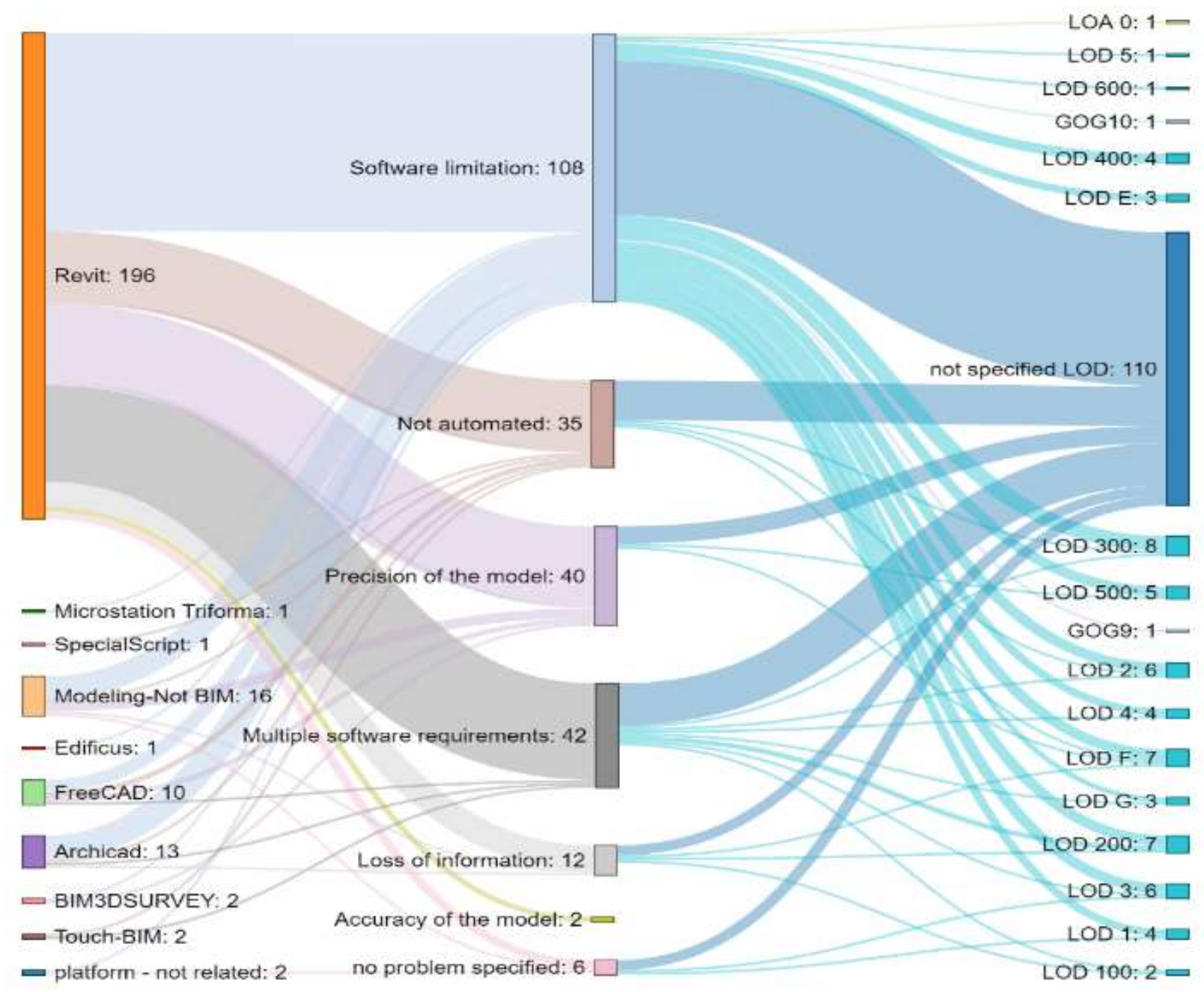

Figure 15. Relationship between Software, Problems and LOD Levels

When the graph above is examined, software constraints are seen as the most important problem in almost all studies. Since we do not have a specialized software produced for HBIM, the result is natural. It was necessary to use more than one software to process the point cloud and model complex forms, and this was reflected in the results as a problem.

\section{EVALUATION AND CONCLUSION} There is no doubt that, the more accurate the determination, structural analysis and documentation of the current state of the building in the protection of architectural heritage, the more successful it will be to transfer it to future generations. In the documentation process made with traditional 
methods, collecting all necessary data such as geometrical and non-geometrical features (color, texture, material), historical information, and surroundings of the building and presenting them simultaneously to the use of all stakeholders are very difficult and errorprone processes. The BIM approach has proven itself in the design, manufacture and operation of new structures. In the studies we examined, the desire to use these advantages of BIM for the protection of architectural cultural heritage stands out. With HBIM, it will be possible to obtain a system where we can see the non-visual data of heritage buildings, their geometrical features and their surroundings, and together enable the transfer of updateable data to future generations.

Within the scope of the research, bibliometric mapping and analysis of the studies, which focused on software with the HBIM keyword between 2008-2021 on the Web of Science database, were performed through VOSViewer and SankeyMATIC. It has been examined how the modeling tools used in HBIM have changed since the first day, and interpretations were made about what expects experts working in this field in the future. When we look at the most cited areas and studies on HBIM, Y.Arayic1 and M.Murphy are the researchers who established the foundations of HBIM, while R. Brumana and F. Banfi among 155 authors have the highest number of authors, which shows that the prominent names can change over time.

Although ArchiCAD was the first software used in HBIM, at the end of the research, Revit was found to be the most prominent software among all platforms. In addition, open source BIM software such as FreeCAD and Edificus have also been used for HBIM purposes over the years. Considering the ratios, it is seen that many software are included in the modeling process, although Revit has the largest ratio. This situation let us think that other software is needed for HBIM where Revit is not sufficient. It should be underlined that the variety of software needed throughout the process may cause the problem of the budget allocated for the software and the need for qualified personnel to use each software. In this context, in the future studies, it is important to investigate whether HBIM is really fast and economical in recording data on heritage buildings. From this perspective, it is possible to argue that HBIM does not respond as expected when it comes to processing data on a single platform.

Researches argues that some problems have been encountered in the modeling stages of heritage buildings. It is possible to say that the most common problem within the scope of the research is the software limitations due to the BIM software being designed for modeling existing structures and aiming to reach standard object solutions. Heritage buildings contain large and complex data, and multiple applications are required to process and transfer this data to BIM software. Looking at the file extensions used to ensure integration between these applications, IFC, OBJ, DWG and DXF came to the front. Information loss may occur during data transfer between these files. However, it is not known how much data has been lost yet. It is thought that the loss of information due to data loss should be studied in future studies.

Despite the problems encountered in the modeling process, the availability of many file formats is also seen as an advantage that enables experts from different disciplines to work together. In addition, the number of BIM software used in HBIM has increased over time. It is thought that this number will gradually increase with the development of technology in the coming years.

The last but not the least, considering the potentials of BIM, with HBIM, the heritage building model can be transferred to future generations, the heritage building model can be updated with new information in the future, and a great knowledge can be created by associating heritage buildings with each other. From this respect, future work should focus on customized BIM software to model the existing structure to reduce the problems encountered and achieve higher LoD levels. 


\section{REFERENCES}

Abbate, E., Invernizzi, S., \& Spano, A.2020.

HBIM Parametric Modelling From Clouds to Perform Structural Analyses Based on Finite Elements: A Case Study on A Parabolic Concrete Vault. Applied Geomatics.

Adami, A., Scala, B., Spezzoni, A. 2017. Modelling And Accuracy In A Bim Environment for Planned Conservation: The Apartment of Troia of Giulio Romano. 3d Virtual Reconstruction and Visualization of Complex Architectures, 42-2(W3):17-23.

Al-Muqdadi, F. 2020. Assessing The Potentials of Heritage Building Information Modelling (HBIM) in Damaged Heritage Reconstruction. Paper Presented at The Heritage BIM in Damaged Heritage Reconstruction.

Allegra, V., Di Paola, F., Butto, M., Vinci, C. 2020. Scan-To-Bim For The Management of Heritage Buildings: The Case Study of The Castle Of Maredolce (Palermo, Italy). ISPRS International Archives of The Photogrammetry, Remote Sensing and Spatial Information Sciences, XLIII(B2):1355-1362.

Angulo-Fornos, R., \& Castellano-Roman, M. 2020. HBIM As Support of Preventive Conservation Actions in Heritage Architecture. Experience of The Renaissance Quadrant Facade of The Cathedral Of Seville. Applied Sciences-Basel, 10(7).

Anton, D., Medjdoub, B., Shrahily, R., \& Moyano, J. 2018. Accuracy Evaluation of The SemiAutomatic 3D Modeling for Historical Building Information Models. International Journal of Architectural Heritage, 12(5):790805.

Antonopoulou, S., Bryan P. 2017. BIM For Heritage: Historic England.

Arayici, Y. 2008. Towards Building Information Modelling for Existing Structures. Structural Survey, 26(3):210-222.

Arayici, Y., Counsell, J., Mahdjoubi, L., Nagy, G., Hawwās, S. Z., Dweidar, K. 2017. Heritage Building Information Modelling. New York: Routledge/Taylor \& Francis Group.

Azhar, S. 2011. Building Information Modeling (BIM): Trends, Benefits, Risks, And Challenges For The AEC Industry. Leadership and Management In Engineering, 11(3): 241252.

Bagnolo, V., Argiolas, R., Cuccu, A. 2018. Digital Survey And Algorithmic Modeling In HBIM. Towards A Library Of Complex Construction Elements. In R. Hassan, I. R. Karas, U. Isikdag, \& A. A. Rahman (Eds.), 5th International Conference On Geoinformation Science - Geoadvances 2018: Isprs Conference on Multi-Dimensional \& Multi-Scale Spatial Data Modeling, 42(4):25-31.

Biagini, C., Ottobri, P. , Banti, N., Bongini, A. 2020. Validation Processes Of H-Bim Models: A Case Study. Paper Presented at The IOP Conference Series: Materials Science and Engineering.

Boeykens, S., Himpe, C., Martens, B. 2012. A Case Study of Using BIM In Historical Reconstruction The Vinohrady Synagogue In Prague. Ecaade 2012, 1(1):729-737.

Brumana, R., Della Torre, S., Previtali, M., Barazzetti, L., Cantini, L., Oreni, D., \& Banfi, F. 2018. Generative HBIM Modelling To Embody Complexity (LOD, LOG, LOA, LOI): Surveying, Preservation, Site Interventionthe Basilica Dicollemaggio (L'Aquila). Applied Geomatics, 10(4):545-567.

Bruno, S., De Fino, M., \& Fatiguso, F. 2018. Historic Building Information Modelling: Performance Assessment for Diagnosis-Aided Information Modelling and Management. Automation in Construction, 86: 256-276.

Bruno, S., Musicco, A., Fatiguso, F., Dell'Osso, G. R. 2019. The Role Of 4D Historic Building Information Modelling And Management in The Analysis Of Constructive Evolution and Decay Condition Within The Refurbishment Process. International Journal Of Architectural Heritage.

Chenaux, A., Murphy, M. ,Pavia, S., Fai, S., Molnar, T., Cahill, J., Lenihan, S., Corns, A. 2019. A Review Of 3d Gis For Use In Creating Virtual Historic Dublin. ISPRS - International Archives of The Photogrammetry, Remote Sensing and Spatial Information Sciences, XLII-2/W9(W9):249-254.

Chiabrando, F., Sammartano, G., \& Spanò, A. 2016. Historical Buildings Models And Their Handling Via 3d Survey: From Points Clouds To User-Oriented Hbim. ISPRS - International 
Archives of The Photogrammetry, Remote Sensing And Spatial Information Sciences, XLI(B5):633-640.

Chow, L., Graham, K., Grunt, T., Gallant, M., Rafeiro, J., \& Fai, S. 2019. The Evolution Of Modelling Practices On Canada's Parliament Hill:An Analysis Of Three Significant Heritage Building Information Models (Hbim). 2nd International Conference Of Geomatics And Restoration, 42-2(W11): 419426.

Cobo, M. J., López-Herrera, A. G., HerreraViedma, E., \& Herrera, F. 2011. Science Mapping Software Tools: Review, Analysis, And Cooperative Study Among Tools. Journal Of The American Society For Information Science And Technology, 62(7):1382-1402.

Conti, A., Fiorini, L., Massaro, R., Santoni, C., Tucci, G. 2020. HBIM For The Preservation Of A Historic Infrastructure: The Carlo III Bridge Of The Carolino Aqueduct. Applied Geomatics.

Çelik, M. Ö., Hamal,S.N.G. , Yakar,İ. 2020. Yersel Lazer Tarama (YLT) Yönteminin Kültürel Mirasın Dokümantasyonunda Kullanımı: Alman Çeşmesi Örneği. Türkiye LIDAR Dergisi, 2(1): 15-22.

Diara, F., \& Rinaudo, F. (2020). IFC Classification For FOSS HBIM: Open Issues And A Schema Proposal For Cultural Heritage Assets. Applied Sciences-Basel, 10(23).

Dore, C., Murphy, M. (201. Current State Of The Art Historic Building Information Modelling. In J. Hayes, C. Ouimet, M. S. Quintero, S. Fai, \& L. Smith (Eds.), Icomos/Isprs International Scientific Committee On Heritage Documentation, 42(2):185-192.

Dore, C., Murphy, M., Mccarthy, S., Brechin, F. , Casidy, C. , Dirix, E. 2015. Structural Simulations And Conservation Analysis Historic Building Information Model (HBIM). In D. Gonzalezaguilera, F. Remondino, J. Boehm, T. Kersten, \& T. Fuse (Eds.), 3d-Arch 2015 - 3d Virtual Reconstruction And Visualization Of Complex Architectures, 40(5):351-357.

Facundo, L., Lerones, P., Llamas, J., GómezGarcía-Bermejo,J., Zalama, E. 2018. A Review Of Heritage Building Information
Modeling (H-BIM). Multimodal Technologies And Interaction, 2(2).

Güleç, S. 2007. Yersel Fotogrametri Yöntemleri Rölöve Alım Tekniğinin Taç Kapılarda Uygulanışı Konya Örnekleri. Selçuk Üniversitesi, Konya.

Jiang, Y. H., Li, A. Q., Xie, L. L., Hou, M. L., Qi, Y., \& Liu, H. Y. 2020. Development And Application Of An Intelligent Modeling Method For Ancient Wooden Architecture. ISPRS International Journal Of GeoInformation, 9(3).

Kamaruzaman, N. (2019). Historic Building Information Modelling (Hbim): A Review. Paper Presented At The 4th International Conference On Rebuilding Place.

Koncsag, M. E., \& Man, I. M. (2015). The Integration Of Cad Instruments And Databases For The Historical Monuments Records In The Area Of Bighi, Malta. Journal Of Applied Engineering Sciences, 5(2): 37-41.

Korumaz, M. 2016. Kültürel Mirasin 3d Belgelenmesinde Yersel Lazer Tarama Teknolojisinin Kullanimi: Aksaray'da Sivil Mimarlik Örneği Alan Çalişmasi. SelçukTeknik Dergisi, 15(2).

Logothetis, S., Delinasiou, A. , Stylianidis, E. 2015. Building Information Modelling For Cultural Heritage: A Review. In Y. N. Yen, K. H. Weng, \& H. M. Cheng (Eds.), 25th International Cipa Symposium 2015.

Logothetis, S., Karachaliou, E., \& Stylianidis, E. 2017. From Oss Cad To Bim For Cultural Heritage Digital Representation. 3d Virtual Reconstruction And Visualization Of Complex Architectures, 42-2(W3):439-445.

Lopez, F. J., Lerones, P. M., Llamas, J., GomezGarcia-Bermejo, J., \& Zalama, E. 2018. Linking HBIM Graphical And Semantic Information Through The Getty AAT: Practical Application To The Castle Of Torrelobaton. Florence Heri-Tech - The Future Of Heritage Science And Technologies, 364.

Macher, H., Landes, T., \& Grussenmeyer, P. 2017. From Point Clouds To Building Information Models: 3D Semi-Automatic Reconstruction Of Indoors Of Existing Buildings. Applied Sciences-Basel, 7(10). 
Murphy, M. 2012. Historic Building Information Modelling. (Phd). Trinity College Dublin.

Murphy, M., Corns, A., Cahill, J., Eliashvili, K., Chenau, A., Pybus, C., Shaw, R., Devlin, G., Deevy, A., Truong-Hong, L. 2017. Developing Historic Building Information Modelling Guidelines And Procedures For Architectural Heritage In Ireland. ISPRS - International Archives Of The Photogrammetry, Remote Sensing And Spatial Information Sciences, XLII-2(W5):539-546.

Murphy, M., Dore, C. 2014. Semi-Automatic Generation Of As-Built Bim Façade Geometry From Laser And Image Data. Electronic Journal Of Information Technology In Construction.

Murphy, M., Mcgovern, E., Pavia, S. 2009. Historic Building Information Modelling (HBIM). Structural Survey, 27(4):311327Nieto, J. E., Moyano, J. J., Rico, F., Anton, D. 2016. Management Of Built Heritage Via The Hbim Project: A Case Study Of Flooring And Wall Tiling. Virtual Archaeology Review, 7(14):1-12.

Oreni, D., Brumana, R. , Georgopoulos, A., \& Cuca, B. .201. HBIM For Conservation And Management Of Built Heritage: Towards A Library Of Vaults And Wooden Bean Floors. ISPRS Annals Of The Photogrammetry, Remote Sensing And Spatial Information Sciences, 2-5.

Oreni, D. B., R.; A. Georgopoulos; B. Cuca. 2014. HBIM Library Objects For Conservation And Management Of Built Heritage. International Journal Of Heritage In The Digital Era.

Osello, A., Lucibello, G., Morgagni, F. 2018. HBIM And Virtual Tools: A New Chance To Preserve Architectural Heritage. Buildings, $8(1)$.

Palomar, I. J., Valldecabres, J. L. G., Tzortzopoulos, P., Pellicer, E.2018. Protocol To Manage Heritage-Building Interventions Using Heritage Building Information Modelling (HBIM).

Pellicer, E., Jordan, I. 2016. BIM Scientific Literature Review For Existing Buildings And A Theoretical Method: Proposal For Heritage Data Management Using HBIM. In J. L. Perdomo-Rivera, A. Gonzalez-Quevedo, C. Lopez Delpuerto, F. Maldonado-Fortunet, \&
O. I. Molina-Bas (Eds.), Construction Research Congress 2016: Old And New Construction Technologies Converge In Historic San Juan.

Pocobelli, D. P., Boehm, J., Bryan,P., Still, J., Grau-Bove,J. 2018. BIM For Heritage Science: A Review. Heritage Science, 6.

Quattrini, R., Malinverni, E. S., Clini, P., Nespeca, R., \& Orlietti, E. 2015. From Tls To Hbim. High Quality Semantically-Aware 3d Modeling Of Complex Architecture. In D. Gonzalezaguilera, F. Remondino, J. Boehm, T. Kersten, \& T. Fuse (Eds.), 3d-Arch 2015 - 3d Virtual Reconstruction And Visualization Of Complex Architectures 40(5):367-374.

Radanovic, M., Khoshelham, K., Fraser, C. 2020. Geometric Accuracy And Semantic Richness In Heritage BIM: A Review. Digital Applications In Archaeology And Cultural Heritage, 19.

Rua, H., \& Gil, A. (2014). Automation In Heritage - Parametric And Associative Design Strategies To Model Inaccessible Monuments: The Case-Study Of Eighteenth-Century Lisbon Águas Livres Aqueduct. Digital Applications In Archaeology And Cultural Heritage, 1(3-4):82-91.

Rubio, M. J. ,Pitarch,M. J. 2019. The Diffusion Of Architectural Heritage, Through Social Networks, As A Digital Heritage.

Scianna,A., Gaglio, F. G., M. La Guardia. 2020. HBIM Data Management In Historical And Archaeological Buildings. Archeologia E Calcolatori,31(1): 231-252.

Simeone, D., Cursi,S., Toldo, I., Carrara,G.2014. B(H)IM - Built Heritage Information Modelling. Digital Heritage,1(1):613-621.

Sun, Z., Xie, J. T., Zhang, Y. Y., Cao, Y. K. 2019. As-Built BIM For A Fifteenth-Century Chinese Brick Structure At Various Lods. ISPRS International Journal Of GeoInformation, 8(12Volk, R., Stengel, J., Schultmann, F. 2014. Building Information Modeling (BIM) For Existing Buildings Literature Review And Future Needs. Automation In Construction, 38:109-127.

Woodward, A., \& Heesom, D. 2019 Implementing HBIM On Conservation Heritage Projects Lessons From Renovation Case Studies. 
International Journal Of Building Pathology And Adaptation.

Worrell, L. L. 2015. Building Information Modeling (BIM): The Untapped Potential For Preservation Documentation And Management. Clemson University.

Wuni, I. Y., Shen, G. Q. P., \& Osei-Kyei, R. 2019. Scientometric Review Of Global Research Trends On Green Buildings In Construction Journals From 1992 To 2018. Energy And Buildings, 190:69-85.

Yang, L., Cheng, J. C. P., \& Wang, Q. 2020. SemiAutomated Generation Of Parametric BIM For Steel Structures Based On Terrestrial Laser Scanning Data. Automation In Construction, 112.

Yang, X. C., Lu, Y. C., Murtiyoso, A., Koehl, M., \& Grussenmeyer, P. 2019. HBIM Modeling From The Surface Mesh And Its Extended Capability Of Knowledge Representation. ISPRS International Journal of GeoInformation, 8(7). 
ATA Planlama ve Tasartm Dergisi, 2021;5:2

$-80-$ 